\title{
The effect of delivery type on neonatal blood indices in an Iranian population
}

\author{
Parastoo Baharvand ${ }^{1}$, Majid Fathi' ${ }^{2}$, Hossein Eliyasy ${ }^{2}$, Babak Abdolkarimi ${ }^{3}$, Ali Asghar Kiani ${ }^{4}, *$
}

${ }^{1}$ Department of Social Medicine, Lorestan University of Medical Sciences, Khorramabad, Iran

${ }^{2}$ Student Research Committee, Lorestan University of Medical Sciences, Khorramabad, Iran

${ }^{3}$ Department of Pediatrics Hematology Oncology, Lorestan University of Medical Sciences, Khorramabad, Iran

${ }^{4}$ Department of Hematology and Blood Transfusion, Lorestan University of Medical Sciences, Khorramabad, Iran

\section{Correspondence}

Ali Asghar Kiani, Department of Hematology and Blood Transfusion, Lorestan University of Medical Sciences, Khorramabad, Iran

Email: aliakianii@gmail.com

History

- Received: 08 July 2018

- Accepted: 04 October 2018

- Published: 27 October 2018

DOI :

https://doi.org/10.15419/bmrat.v5i10.492

\section{Check for updates}

\section{Copyright}

(- Biomedpress. This is an openaccess article distributed under the terms of the Creative Commons Attribution 4.0 International license.

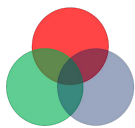

\begin{abstract}
Background: Generally, there are two methods for childbirth: normal vaginal and cesarean section (C-section). Each method has advantages and complications. In this study, we investigated the effects of type of delivery on hematological parameters in healthy full-term neonates in an Iranian population, from 2016-2017. Materials: Three hundred pregnant women, along with their healthy and term babies, were studied. According to the route of delivery, the neonates were divided into two groups: vaginal $(n=150)$ and C-section $(n=150)$. Complete blood count $(C B C)$ and peripheral blood smear (PBS) were performed on the neonates from umbilical cord blood immediately after birth. Data were analyzed by using SPSS V. 22 and statistical analyses were done by student's t-test and correlation tests, with P-value $<0.05$ set as the lowest limit of significance. Results: We observed a significant increase in hematologic parameters, such as red blood cell (RBC) count, hemoglobin, hematocrit, red cell distribution width (RDW), platelets, total leukocyte count and neutrophil count, in full-term neonates who delivered vaginally compared to those delivered by cesarean section $(p<0.001)$. However, there was no significant difference between the delivery types in terms of mean corpuscular volume (MCV), mean corpuscular hemoglobin $(\mathrm{MCH})$, mean corpuscular hemoglobin concentration (MCHC), mean platelet volume (MPV), platelet distribution width (PDW), eosinophil count, lymphocyte count, or monocyte count. Conclusion: According to our study, the mode of delivery influences the hematological parameters in full-term neonates; thrombocytopenia and anemia in neonates were associated with cesarean section delivery. Thus, we recommend that pregnant women do not deliver by C-section unless in emergency situations. Key words: Blood indices, Delivery type, Iran, Neonate
\end{abstract}

\section{INTRODUCTION}

Childbirth is one of the divine gifts for procreation and increasing the human population on earth, from the time of Adam and Eve to now. The mechanism of childbirth is a self-sustaining process with no need for external intervention. If the childbirth is dangerous for the fetus or mother, a cesarean section (C-section) can help to save the mother's or baby's life ${ }^{1,2}$.

Unfortunately, nowadays, the prevalence of C-section in most of the developed countries has reached more than $50 \%$, and indeed, in many societies childbirth by this method has turned into a cultural trend such that more than half of women voluntarily prefer to have a C-section $^{3-5}$. Thus, in addition to increasing the mother's risk of death after performing this surgery, as well as creating physical and psychological complications, C-section can increase costs for the mother and her family by 2-3 fold. Moreover, mothers who experience disabilities after $\mathrm{C}$-section are prone to inattention, less care, and incorrect breastfeeding after the birth of the newborn ${ }^{6,7}$.

C-sections are typically limited to special, emergency cases in which childbirth through the natural channel isn't possible or when serious dangers are posed for mother and fetus. Thus, the use of C-section surgery is restrictive. It is not the preferred method for childbirth since like other surgeries, it is accompanied with risks and complications for mother and fetus ${ }^{8,9}$, in comparison to vaginal childbirth. Indeed, the rate of mortality from C-section is 7 -fold greater than that for natural childbirth ${ }^{10}$. Owing to the complications C-section poses to mother and fetus, in recent years, international organizations such as the World Health Organization have emphasized that this type of childbirth delivery should only be performed based on the clinical dangers for the mother ${ }^{11,12}$.

When vaginal birth occurs naturally, without use of instruments and medications, the newborn immediately has skin contact with the mother, and this can increase the possibility of breastfeeding ${ }^{13}$. The pain of natural childbirth causes the production of oxytocin, epinephrine, and adrenaline which have important roles in facilitating responses between mother and newborn, as well as in early breastfeeding postdelivery ${ }^{14-16}$. On the other hand, the breastfeeding period is the most sensitive period for growth and 
evolution in the human life and, thus, correct infant feeding plays an important role in this period. Breast milk is the most complete food for infants in the first few months after birth ${ }^{17,18}$.

Breast milk includes different protective immunological substances, such as immunoglobulins and growth factors. Human milk contains antibodies produced against the mother's peripheral antigens, such as $E$. coli. As a result, infants fed by breast milk are less susceptible to intestinal infections ${ }^{19-22}$, and are more protected against rotavirus which can cause infantile gastroenteritis $^{23}$. Furthermore, breastfeeding can decrease the risk of atopic dermatitis and respiratory infections ${ }^{24}$. A mother's milk contains both $\mathrm{T}$ and $\mathrm{B}$ lymphocytes. T lymphocytes in breast milk are different from those found in the blood; T cells in breast milk particularly present specific antigens. It is suggested an infant benefits from the mother's immunological experiences via the memory $\mathrm{T}$ lymphocytes in the milk ${ }^{25-27}$. For the first newborn, the hematological indexes (such as leukocytes, hematocrit, platelets, and hemoglobin) were higher than those for the second and third newborn.

In women with high parity due to frequent childbirth and menstrual cycles, iron deficiency is greater than in nulliparous women ${ }^{28-30}$. Iron deficiency increases the risk of preterm childbirth and low weight in newborns. In fact, in low weight and premature infants, hematocrit levels are decreased ${ }^{31}$. On the other hand, in women with high parity, natural childbirth or Csection is accompanied by less stress, in comparison to nulliparous women, because of previous childbirth experience and short deliveries. Moreover, the leukocyte and neutrophil counts in nulliparous women are higher because of the high rate of cortisol ${ }^{32,33}$.

Sexual hormones (like testosterone) are one of the reasons of why hematocrit levels are increased in males during puberty. Various studies have reported that levels of testosterone among male infants are higher than among female ones ${ }^{34}$. According to the studies, the level of umbilical vein testosterone in male newborns is significantly higher than that in female newborns. It seems that one of the reasons for high hematocrit in male infants is the higher level of testosterone in males versus female infants ${ }^{35,36}$. During puberty, sexual steroids such as estrogen and progesterone will increase; these hormones impress hematopoiesis and play a role in the reduction of hemoglobin in the pregnancy period. The levels of the steroid hormones (estrogen and progesterone) are high, while the mother's hemoglobin concentration is reduced during the pregnancy period ${ }^{37}$.
It has been hypothesized that female infants may have the sexual hormones as those in the puberty period, as well as lower levels of hemoglobin than male infants $^{38}$. The infant levels of hemoglobin and hematocrit depend on various factors. The delayed close of the umbilical cord can increase infant hemoglobin levels up to $20 \%$. Also, if the placenta is cut off and interrupted, and/or one of the fetus vessels is pierced or torn and the infant is kept significantly above the level of the placenta before closing the cord, the hemoglobin concentration may be decreased after childbirth $^{39}$. Factors such as early birth, anemia during pregnancy, and C-section can also decrease levels of hemoglobin at the beginning of birth and can be followed by accelerated or intensified anemia ${ }^{40-42}$

Accordingly, the type of childbirth can have different effects on various infant hematological factors. Thus, it is also important to determine and understand the neonatal blood indices as it relates to childbirth effects. In this study, an Iranian population was evaluated with the purpose of surveying and comparing the effects of natural childbirth versus C-section on infant hematological factors.

\section{METHODS}

\section{Study population}

Patients included in this study consisted of healthy male newborns born by normal delivery or nonemergency C-section, whose mothers were at gestational age greater than 38 weeks, with positive $\mathrm{RH}$ and non-O blood type, without underlying illness and anemia, and referred to the Aslian Hospital (Khorramabad) or Imam Khomeini Hospital (Aleshtar) in 2017. Due to the exclusion of all possible interactions, we only selected male neonates. To prevent possible $\mathrm{ABO}$ and $\mathrm{Rh} \mathrm{HDN}$ (hemolytic disease of the newborns), mothers with $\mathrm{O}$ blood group and $\mathrm{Rh}$ negative were excluded from the study. Any underlying disease and anemia may affect the blood indices so we excluded all mothers (and her babies) with these conditions.

\section{Research and information gathering}

In this cross-sectional study, 300 umbilical cord blood samples were taken from 300 neonates, including 150 neonates delivered naturally and 150 cases of neonates delivered by $\mathrm{C}$-section. All of the newborns were of male gender and had not shown any abnormal findings in the primary examination. Subsequently, accurate records were gathered for the mothers such as maternal hospital records, information about the number of pregnancies, underlying illnesses, and 
hemoglobin levels. Only those mothers and infants who had met these criteria or parameters were included in the study; any mother and infant who did not have the above conditions were excluded.

Two $\mathrm{mL}$ blood samples from the umbilical cord were taken immediately after closing the umbilical cord and were poured in a special test tube, which contains an anti-coagulant ethylenediaminetetraacetic acid (EDTA), and slowly shaken to prevent clotting. Peripheral blood slides were immediately prepared and used for morphological examination of blood cells. Samples were analyzed by a calibrated counter (Sysmex KX 21N) in three hours. For samples that were left for more than three hours (maximum 6 hours), it was not possible to test them that day and they were placed in the refrigerator at $4^{\circ} \mathrm{C}$. It should be noted that all mothers were satisfied verbally and were told that there was no danger to the baby and mother during the umbilical cord blood sampling. Blood samples were collected after clamping the umbilical cord at a site of the umbilical cord still attached to the infant.

\section{Data Analysis}

The statistical software used to analyze the data was SPSS version 11.5. Independent t-test and MannWhitney test were used to compare the indices between the two groups. Chi-square test was also used to measure the relationship between two qualitative variables.

\section{Ethical Statements}

This study is licensed with code LUMS.REC.1396.229 from the Ethics Committee of Lorestan University of Medical Sciences, Iran.

\section{RESULTS}

The blood cell parameters of the 150 neonates of Csection and 150 neonates of normal delivery by mothers who were referred to Asalian Hospital (Khorramabad) and Imam Khomeini Hospital (Aleshtar), from February 19, 2017 to September 22, 2017, were examined. The mean age of the mothers was $25.9 \pm 2.65$ in the vaginal delivery group and $26.4 \pm 3.45$ in the cesarean group; there was no underlying disease in both groups. All mothers had RH blood+ type and were pregnant for the second time. Mothers with blood group $\mathrm{O}$ were excluded from the study in order to prevent possible immune interference between mother and fetus. The average maternal hemoglobin in normal delivery was $12.9 \pm 0.89$ and in the $\mathrm{C}$-section was $13.04 \pm 0.77$. There was no significant difference between the two groups $(\mathrm{P}=0.649)$.
The mean neonatal hemoglobin, hematocrit, red blood cell (RBC) count, and RDW in normal delivery were $14.9 \pm 1.3 \mathrm{~g} / \mathrm{dL}, 44 \pm 1.4 \%, 5.05 \pm 0.007 \times 10^{12} / \mathrm{L}$, and $17.94 \pm 4.1 \%$, respectively; the corresponding parameters for delivery by $\mathrm{C}$-section were $14.09 \pm 1.2$ $\mathrm{g} / \mathrm{dL}, 42 \pm 3.7 \%, 4.4 \pm 0.008 \times 10^{12} / \mathrm{L}$, and $16.3 \pm 3.2 \%$, respectively (Table 1 ). There was a significant difference between all groups $(\mathrm{p}<0.001)$. There were no significant differences in other RBC indices, such as mean corpuscular volume (MCV), mean corpuscular hemoglobin $(\mathrm{MCH})$, and mean corpuscular hemoglobin concentration $(\mathrm{MCHC})(\mathrm{P}>0.05)$. The mean white blood cell (WBC), neutrophil count, and lymphocyte count of neonates in normal delivery were $18.3 \pm 8 \times 10^{9} / \mathrm{L}, 58 \pm 7 \%$, and $34 \pm 7 \%$, respectively; in C-section, they were $7.78 \pm 3 \times 10^{9} / \mathrm{L}$, $38 \pm 8 \%$ and $57 \pm 8 \%$, respectively. Notably, a p-value of $\mathrm{P}<0.001$ indicated that there was a significant difference between the two groups in all parameters The mean percentage of the infant's monocytes and eosinophils in normal delivery were $4.0 \pm 0.85 \%$ and $7.1 \pm 0.36 \%$, respectively; in cesarean delivery those values were $4 \pm 0.81 \%$ and $1.7 \pm 0.27 \%$, respectively (Table 2). There were no significant differences between the two groups $(\mathrm{p}=0.836)$.

The average platelet count, mean platelet volume (MPV), and PDW of neonates of normal delivery were $305 \pm 82 \times 10^{9} / \mathrm{L}, 9.84 \pm 0.64$ femtoliter (fL), and $12.18 \pm 2.03 \%$, respectively. In those delivered by Csection, the corresponding parameters were $242 \pm 92$ $\mathrm{x} 10^{9} / \mathrm{L}, 9.87 \pm 0.65 \mathrm{fL}$, and $11.88 \pm 1.7 \%$, respectively. There was a significant difference between all groups $(\mathrm{P}<0.001$; Table 3$)$.

The anemia rate of infants in normal delivery versus C-section was $34 \%$ versus $53 \%$, respectively. There was significant relationship between the type of delivery and anemia $(\mathrm{P}<0.001)$. Also, the rate of thrombocytopenia in infants was $1 \%$ in normal delivery and $7 \%$ in $\mathrm{C}$-section. Since $\mathrm{P}<0.001$, this indicated a significant relationship between the type of delivery and anemia (Table 4).

\section{DISCUSSION}

For a long time, there has been discussion about the advantages and disadvantages of the types of childbirth on mothers and infants. Many studies have been conducted to evaluate the effects of childbirth, in various aspects, on both mother and infant. In the study herein, we evaluated 300 male term neonates for their cord blood indexes; these neonates were born from mothers who had come to Imam Khomeini Hospital (Aleshtar city) and Asalian Hospital (Khorramabad city) for selective natural childbirth or C-section, 


\begin{tabular}{|c|c|c|c|c|}
\hline \multirow{4}{*}{ Row } & \multirow{4}{*}{ Blood parameter } & \multicolumn{2}{|c|}{ Delivery type } & \multirow{4}{*}{$P$-value } \\
\hline & & & & \\
\hline & & C-section & Normal delivery & \\
\hline & & Mean \pm SD & Mean \pm SD & \\
\hline 1 & Hemoglobin (gram/dL) & $14.09 \pm 1.2$ & $14.9 \pm 1.3$ & $<0.001$ \\
\hline 2 & Hematocrit (\%) & $42 \pm 3.7$ & $44 \pm 1.4$ & $<0.001$ \\
\hline 3 & $\operatorname{RBC}\left(\mathrm{x} 10^{12} / \mathrm{L}\right)$ & $4.4 \pm 0.008$ & $5.05 \pm 0.007$ & $<0.001$ \\
\hline 4 & MCV (femtoliter) & $106 \pm 5.7$ & $107 \pm 5.9$ & 0.524 \\
\hline 5 & $\mathrm{MCH}$ (picogram) & $34.4 \pm 3.3$ & $34.6 \pm 3.2$ & 0.591 \\
\hline 6 & $\mathrm{MCHC}(\mathrm{gram} / \mathrm{dL})$ & $34.15 \pm 1.15$ & $34.41 \pm 1.19$ & 0.452 \\
\hline 7 & RDW (\%) & $16.3 \pm 3.2$ & $17.94 \pm 4.1$ & $<0.001$ \\
\hline
\end{tabular}

RBC: red blood cell; MCV: mean cell volume; MCH: mean cell hemoglobin; MCHC: mean cell hemoglobin concentration; RDW: red cell distribution width

\begin{tabular}{clccc}
\multicolumn{2}{c}{ Table 2: Comparison of white blood cell-related neonatal blood in normal delivery versus cesarean section } \\
\hline Row & Blood parameter & Delivery type & P-value \\
& & $\begin{array}{c}\text { C-section } \\
\text { Mean } \pm \text { SD }\end{array}$ & $\begin{array}{c}\text { Normal delivery } \\
\text { Mean } \pm \text { SD }\end{array}$ & \\
& & $38 \pm 8$ & $58 \pm 7$ & $<0.001$ \\
1 & Mean neutrophil (\%) & $57 \pm 8$ & $34 \pm 7$ & $<0.001$ \\
2 & Lymphocyte (\%) & $4 \pm 0.81$ & $4 \pm 0.85$ & 0.836 \\
3 & Monocyte (\%) & $1.7 \pm 0.27$ & $1.7 \pm 0.36$ & 0.822 \\
4 & Eosinophil (\%) & $7.78 \pm 3$ & $18.3 \pm 8$ & $<0.001$ \\
5 & WBC count $\left(\mathrm{x} 10^{9} / \mathrm{L}\right)$ & & &
\end{tabular}

WBC: white blood cell

Table 3: Comparison of platelet-related neonatal blood factors in normal delivery versus cesarean section

\begin{tabular}{|c|c|c|c|c|}
\hline \multirow{3}{*}{ Row } & \multirow{3}{*}{ Blood factor } & \multicolumn{2}{|c|}{ Delivery type } & \multirow{3}{*}{ P-value } \\
\hline & & C-section & Normal delivery & \\
\hline & & Mean $\pm S D$ & Mean \pm SD & \\
\hline 1 & $\begin{array}{l}\text { Platelet average } \quad(\mathrm{x} \\
\left.10^{9} / \mathrm{L}\right)\end{array}$ & $242 \pm 92$ & $305 \pm 82$ & $<0.001$ \\
\hline 2 & MPV (fL) & $9.87 \pm 0.65$ & $9.84 \pm 0.64$ & 0.684 \\
\hline 3 & PDW (\%) & $11.88 \pm 1.7$ & $12.18 \pm 2.03$ & 0.637 \\
\hline
\end{tabular}

MPV: mean platelet volume; PDW: platelet distribution width

from March to September 2017. All of the selected newborns were term neonates who did not show any abnormalities in their first examination. Their mothers did not indicate any background diseases, and all of them were gravida 2 with $\mathrm{A}, \mathrm{B}, \mathrm{AB}$ or $\mathrm{RH}$ positive blood type. Due to the probable immunological incompatibilities between the mother and the embryo, mothers with blood type $\mathrm{O}$ (related to $\mathrm{ABO}$ hemolytic disease of the newborn, i.e. ABO HDN) ${ }^{43}$ were excluded from the study, as were those mothers who were Rh negative.
Among the 300 neonates studied, 150 neonates were born by natural (vaginal) delivery while 150 neonates were born by selective C-section. According to the results of this study, which are based on complete blood count and peripheral blood smear taken from newborns at the beginning of birth, blood indexes such as hemoglobin, hematocrit, RBC, WBC, neutrophil count, platelet count, and RDW were higher in those newborns delivered naturally than in those delivered by $\mathrm{C}$-section. Other blood indexes such as $\mathrm{MCV}$, $\mathrm{MCH}, \mathrm{MCHC}, \mathrm{MPV}, \mathrm{PDW}$, eosinophils, and mono- 


\begin{tabular}{|c|c|c|c|c|}
\hline & \multirow{2}{*}{$\mathrm{p}(.51480000000000004)$} & \multicolumn{2}{|c|}{ Delivery type } & \multirow[b]{2}{*}{ P-value } \\
\hline & & Normal delivery & C-section & \\
\hline \multirow[t]{2}{*}{ Anemia } & $\begin{array}{l}\text { Hemoglobin above } 13.7 \\
(\mathrm{~g} / \mathrm{dL})\end{array}$ & $125(83.3 \%)$ & $25(16.7 \%)$ & \multirow[t]{2}{*}{$<0.001$} \\
\hline & $\begin{array}{l}\text { Hemoglobin below } 13.7 \\
(\mathrm{~g} / \mathrm{dL})\end{array}$ & $92(61.3 \%)$ & $58(38.7 \%)$ & \\
\hline \multirow[t]{2}{*}{ Thrombocytopenia } & $\begin{array}{l}\text { Platelet over } \\
150\left(\text { x } 10^{9} / \mathrm{L}\right)\end{array}$ & $149(0.99)$ & $1(0.01)$ & \multirow[t]{2}{*}{$<0.001$} \\
\hline & $\begin{array}{l}\text { Platelet over } \\
150\left(\times 10^{9} / \mathrm{L}\right)\end{array}$ & $139(0.93)$ & $11(0.07)$ & \\
\hline
\end{tabular}

cytes showed no differences between the two kinds of childbirth. The lymphocytes index did not show a significantly different count between the two types of childbirth. However, babies born by caesarean showed a higher percentage of relative abundance of lymphocytes than those babies born vaginally.

Past studies by others have also investigated the relationship of mode of childbirth delivery and blood indexes. For instance, in 2011, Chang et al. demonstrated that there is no meaningful relationship between the kind of delivery and blood indexes (such as $\mathrm{MCV}, \mathrm{MCHC}$ and $\mathrm{MCH})^{44}$, which is in agreement with our study. Qaiser et al. showed in a crosssectional study, in 2006, that there was no change in $\mathrm{MCV}, \mathrm{MCHC}$, or $\mathrm{MCH}$ in the two kinds of childbirth delivery ${ }^{45}$, which is, again, in agreement with our current study. Moreover, Nikischin et al., in 1997, studied the impact of type of childbirth on the healthy and term newborn's blood indexes. Their study was based in Germany and they demonstrated that there is no relevance between $\mathrm{MCV}, \mathrm{MCHC}$, and $\mathrm{MCH}$ with the type of delivery ${ }^{46}$, which is consistent, too, with the findings of our study.

According to our study, the average hemoglobin in cord blood of babies born by natural delivery is $14.9 \pm 1.3 \mathrm{~g} / \mathrm{dL}$, and in cesarean babies is $14.09 \pm 0.2$ $\mathrm{g} / \mathrm{dL}$. Therefore, infants born by normal delivery show about $0.8 \%$ higher mean hemoglobin. The hematocrit index in newborns born vaginally is $44 \pm 4.1 \%$ and in cesarean newborns is $42 \pm 3.7 \%$; thus, the newborn hematocrit level from neonates of natural birth is approximately $2 \%$ higher than that for cesarean birth. Moreover, the RBC count in vaginal newborns was $5.05 \times 10^{6} / \mu \mathrm{L}$, whereas the count in cesarean newborns was $4.4 \times 10^{6} / \mu \mathrm{L}$ (thus vaginal newborns have $600,000 \mathrm{RBC} / \mu \mathrm{L}$ more than cesarean newborns).

Generally, our results were aligned with study results from Hajia Borna et al. in Tehran in $2004^{47}$, Shahla
Vaziri et al. in Ahvaz in $2003^{48}$, Zibdad et al. at Bahman Gonabad Hospital in $2011^{49}$, Hemmatyar et al. at Najmieh Tehran Hospital in $2005^{50}$, Marwaha et al. in $1992^{51}$, Sheffer et al. in $2003^{52}$, Zhou et al. ${ }^{53}$, Chang et al. in Taiwan in $2011^{54}$, Wu J.H. et al. in Taiwan in $2009^{55}$, Fady et al. in Egypt in $2013^{56}$, Lee et al. in Korea in $1998^{57}$, Acharya et al. in $2009^{58}$, Eskola et al. in $2011^{59}$, and Nogurea et al. in Bono Siro in $1999^{60}$.

In conclusion, the mean of hematological indexes (e.g. hemoglobin, hematocrit, RBC, WBC, neutrophil count, platelet count, and RDW) were higher in neonates who were born by natural childbirth versus those born by cesarean delivery. Other blood indices such as MCV, MCH, MCHC, MPV, PDW, eosinophils, and monocytes did not show any significant difference between the two methods of delivery. On the other hand, $16.7 \%$ of normal birth infants and $38.7 \%$ of $\mathrm{C}$-section birth infants had hemoglobin below $13.7 \mathrm{~g} / \mathrm{dL}$, and approximately 1\% of normal birth infants and 7\% of C-section birth infants had platelet counts below 150,000 platelets/ $\mu \mathrm{L}$. Platelets below $100,000 / \mu \mathrm{L}$ and hemoglobin $<10 \mathrm{~g} / \mathrm{dL}$ were not seen in any of the newborns. The umbilical cord blood hemoglobin of the studied infants was significantly lower than the hemoglobin listed in the Nelson textbook of pediatrics (16.5 \pm 1.5$)$. According to the results of our study, there were higher levels of beneficial blood parameters (such as hemoglobin and hematocrit) in normal birth neonates, but a higher percentage of anemia and thrombocytopenia in cesarean birth neonates.

\section{CONCLUSIONS}

In the current study, although there were some limitations, such as low sample size and few analysis techniques, the findings demonstrate that it is necessary to raise the awareness of parents about the benefits of 
normal delivery and to refrain them from making selective and unnecessary cesareans inasmuch as possible.

\section{COMPETING INTERESTS}

The authors declare no conflict of interest in this investigation.

\section{AUTHORS' CONTRIBUTIONS}

Ali Asghar Kiani: Study design, data collection Majid Fathi: data collection, doing experiments Hossein Eliyasy: data collection, doing experiments Mehdi Birhjandi: data analysis

Babak Abdolkarimi: data collection

Parastoo Baharvand: study design, writing

\section{ACKNOWLEDGMENTS}

The authors should be thankful from the staff of Aslian Hospital (Khorramabad) and Imam Khomeini Hospital (Aleshtar) for helping them in sample collecting.

\section{REFERENCES}

1. Bohren MA, Hofmeyr GJ, Sakala C, Fukuzawa RK, Cuthbert A. Continuous support for women during childbirth. The Cochrane Library. 2017;7:CD003766.

2. Blyholder L, Chumanov E, Carr K, Heiderscheit B. Exercise Behaviors and Health Conditions of Runners After Childbirth. Sports Health. 2017;9:45-51. Available from: Doi:10.1177/ 1941738116673605.

3. Azami-Aghdash S, Ghojazadeh M, Dehdilani N, Mohammadi $M$, Abad RAA. Prevalence and causes of cesarean section in Iran: systematic review and meta-analysis. Iranian Journal of Public Health. 2014;43:545-55.

4. de Vaate AJB, van der Voet LF, Naji O, Witmer M, Veersema S, Brölmann HA. Prevalence, potential risk factors for development and symptoms related to the presence of uterine niches following Cesarean section: systematic review. Ultrasound in Obstetrics \& Gynecology. 2014;43:372-82. Available from: DOI:10.1002/uog.13199.

5. Mylonas I, Friese K. Indications for and risks of elective cesarean section. Deutsches Ärzteblatt International. 2015;112:489-95. Available from: DOI:10.3238/arztebl.2015. 0489.

6. Mueller NT, Whyatt R, Hoepner L, Oberfield S, DominguezBello MG, Widen EM. Prenatal exposure to antibiotics, cesarean section and risk of childhood obesity. International Journal of Obesity. 2015;39:665-70. Available from: DOI: 10.1038/ijo.2014.180.

7. Huang $L$, Chen $Q$, Zhao Y, Wang W, Fang F, Bao Y. Is elective cesarean section associated with a higher risk of asthma? A meta-analysis. The Journal of Asthma. 2015;52:16-25. Available from: Doi:10.3109/02770903.2014.952435.

8. Myers SA, Gleicher N. A successful program to lower cesarean-section rates. The New England Journal of Medicine. 1988:319:1511-6. Available from: Doi:10.1056/ nejm198812083192304.

9. Taffel SM, Placek PJ, Liss T. Trends in the United States cesarean section rate and reasons for the 1980-85 rise. American Journal of Public Health. 1987;77:955-9. Available from: Doi:10.2105/ajph.77.8.955.

10. Osser OV, Jokubkiene L, Valentin L. High prevalence of defects in Cesarean section scars at transvaginal ultrasound examina- tion. Ultrasound in Obstetrics \& Gynecology. 2009;34:90-7. Available from: DOI:10.1002/uog.6395.

11. Tower AM, Frishman GN. Cesarean scar defects: an underrecognized cause of abnormal uterine bleeding and other gynecologic complications. Journal of Minimally Invasive Gynecology. 2013;20:562-72. Available from: DOI:10.1016/j.jmig. 2013.03.008.

12. Negahban T, Jaberei AA, Kazemi M. The preferred delivery method and influenced factors from view of pregnant women referred to Rafsanjan city health and treatment units and clinics. Rafsanjan Uni Med Sci J. 2006:5:161-168.

13. Patel RR, Liebling RE, Murphy DJ. Effect of operative delivery in the second stage of labor on breastfeeding success. Birth (Berkeley, Calif). 2003;30:255-60. Available from: DOI: 10.1046/j.1523-536X.2003.00255.x.

14. Jonas K, Johansson LM, Nissen E, Ejdebäck M, Ransjö-Arvidson $A B$, Uvnäs-Moberg K. Effects of intrapartum oxytocin administration and epidural analgesia on the concentration of plasma oxytocin and prolactin, in response to suckling during the second day postpartum. Breastfeeding Medicine. 2009:4:71-82. Available from: DOI:10.1089/bfm.2008.0002

15. Soltanpour MS, Soheili Z, Pourfathollah AA, Samiei $\mathrm{SH}_{\text {, }}$ Meshkani R, Kiani AA, et al. The A1298C Mutation in Methylenetetrahydrofolate Reductase Gene and Its Association With Idiopathic Venous Thrombosis in an Iranian Population. Laboratory Medicine. 2011;42(v):213-216. Available from: 10.1309/LM5LWXCHVZY9RFOM.

16. Verster A, Mannaerts D, Veken LVD, Maeyer KD, Coppejans $H$ Jacquemyn Y. Protocol for a randomized trial on nausea, vomitus and arterial hypotension comparing carbetocin and oxytocin as prevention for hemorrhage after cesarean section. International Journal of Clinical Trials. 2017;4:28-30.

17. Victora CG, Bahl R, Barros AJ, França GV, Horton S, Krasevec J, et al. Breastfeeding in the 21st century: epidemiology, mechanisms, and lifelong effect. Lancet. 2016;387:475-90. Available from: Doi:10.1016/s0140-6736(15)01024-7.

18. Wambach K, Riordan J. Breastfeeding and human lactation; 2014

19. Cravioto A, Tello A, Villafán H, Ruiz J, del Vedovo S, Neeser JR. Inhibition of localized adhesion of enteropathogenic Escherichia coli to HEp-2 cells by immunoglobulin and oligosaccharide fractions of human colostrum and breast milk. The Journal of Infectious Diseases. 1991;163:1247-55. Available from: DOI:10.1093/infdis/163.6.1247.

20. Kumar T, Kumar S, Sunita MK, Jhillmill A, Sharan A. Study on Effects of Exclusive Breastfeeding on Immunity of Infants. Prof RK Sharma. 2016;7:2300.

21. Bridgman $S L$, Konya $T$, Azad MB, Sears MR, Becker AB, and SET. Infant gut immunity: a preliminary study of IgA associations with breastfeeding. Journal of Developmental Origins of Health and Disease. 2016;7:68-72. Available from: Doi:10.1017/s2040174415007862.

22. Koczo A, Marino A, Jeyabalan A, Elkayam U, Cooper L, Fett J, et al. Cellular Immune Activation and Breastfeeding in Peripartum Cardiomyopathy. 2017;

23. Newburg DS, Peterson JA, Ruiz-Palacios GM, Matson DO, Morrow AL, Shults J. Role of human-milk lactadherin in protection against symptomatic rotavirus infection. Lancet. 1998:351:1160-4. Available from: Doi:10.1016/s0140 6736(97)10322-1.

24. Ip S, Chung M, Raman G, Trikalinos TA, Lau J. A summary of the Agency for Healthcare Research and Quality's evidence report on breastfeeding in developed countries. Breastfeeding Medicine. 2009;4:S17-30. Available from: DOI:10.1089/bfm. 2009.0050 .

25. Verhasselt V. Is infant immunization by breastfeeding possible? Phil Trans R Soc B. 2015;370:20140139.

26. Turfkruyer $M$, Verhasselt $V$. Breast milk and its impact on maturation of the neonatal immune system. Current Opinon in Infectious Diseases. 2015:28:199-206. Available from: Doi: $10.1097 /$ qco.000000000000165. 
27. Maschmann J, Goelz R, Witzel S, Strittmatter U, SteinmassI M, Jahn G. Characterization of human breast milk leukocytes and their potential role in cytomegalovirus transmission to newborns. Neonatology. 2015;107:213-9. Available from: Doi:10.1159/000371753.

28. Cecunjanin Z, Selimović A, Milišić S, Mujić E. ASSESSMENT OF HEMATOLOGICAL PARAMETERS, ACID-BASE STATUS AND ARTERIAL BLOOD GAS TEST BEFORE AND AFTER TREATMENT OF ACUTE BRONCHIOLITIS IN CHILDREN. International Journal of Surgery and Medicine. 2016;2(3):1-1.

29. Panwar C, Kaushik SL, Kaushik R, Sood A. Correlation of neonatal and maternal clinico-hematological parameters as predictors of early onset neonatal sepsis. International Journal of Contemporary Pediatrics. 2016;4:36-42.

30. Gholami M, Abbaszadeh A, Khayat ZK, Anbari K, Baharvand $P$, Gharravi AM. Honey improves spermatogenesis and hormone secretion in testicular ischaemia-reperfusion-induced injury in rats. Andrologia. 2018;50(1):e12804. Available from: 10.1111/and.12804

31. Clark KM, Li M, Zhu B, Liang F, Shao J, Zhang Y. Breastfeeding, mixed, or formula feeding at 9 months of age and the prevalence of iron deficiency and iron deficiency anemia in two cohorts of infants in China. The Journal of Pediatrics. 2017;181:56-61. Available from: DOI:10.1016/j.jpeds.2016.10. 041.

32. Bhandari SD, Joshi S. Perception and perceived experiences about prevention and consequences of teenage pregnancy and childbirth among teenage mothers: A qualitative study. Journal of Advanced Academic Research. 2017;3:164-172.

33. Ganchimeg T, Ota E, Morisaki N, Laopaiboon M, Lumbiganon $P$, and JZ. Pregnancy and childbirth outcomes among adolescent mothers: a World Health Organization multicountry study. BJOG. 2014;121:40-8. Available from: Doi:10.1111/ 1471-0528.12630.

34. Johns LE, Ferguson KK, Soldin OP, Cantonwine DE, RiveraGonzález LO, Toro LVD. Urinary phthalate metabolites in relation to maternal serum thyroid and sex hormone levels during pregnancy: a longitudinal analysis. Reproductive Biology and Endocrinology. 2015;13:4. Available from: Doi:10.1186/14777827-13-4.

35. Butler AM, Charoensiriwatana W, Krasao P, Pankanjanato $R$, Thong-Ngao P, Polson RC. Newborn Thyroid Screening: Influence of Pre-Analytic Variables on Dried Blood Spot Thyrotropin Measurement. Thyroid. 2017;27:1128-34. Available from: DOI:10.1089/thy.2016.0452.

36. Orlandini C, Torricelli M, Spirito N, Alaimo L, Tommaso MD, Severi FM. Maternal anemia effects during pregnancy on male and female fetuses: are there any differences? The Journal of Maternal-Fetal \& Neonatal Medicine. 2017;30:1704-8. Available from: Doi:10.1080/14767058.2016.1222607.

37. Dodd JM, Grivell RM, O'Brien C, Dowswell T, Deussen AR. Prenatal administration of progestogens for preventing preterm birth in women with a multiple pregnancy. Cochrane Database of Systematic Reviews. 2016;.

38. Herruzo AJ, Mozas J, Alarcón JL, López JM, Molina R, Molto L. Sex differences in serum hormone levels in umbilical vein blood. International Journal of Gynaecology and Obstetrics: the Official Organ of the International Federation of Gynaecology and Obstetrics. 1993;41:37-41. Available from: Doi: 10.1016/0020-7292(93)90152-m.

39. Cunningham FG, Leveno KJ, Bloom SL, Hauth JC, Gilstrap LC, Wenstrom KD. Gestational trophoblastic disease. Williams Obstetrics; 2005.

40. Kliegman RM, Stoll BJ. Anemia in the newborn in fant, blood disorders, non infectious disorders, the fetus and the neonatal infant. Behrman RE, kligman RM Arvin, AM Nelson textbook of pediatrics. 2004;p. 599-601.

41. Reinhardt MC, Marti HR. Haematological data of African newborns and their mothers in Abidjan. Helvetica Paediatrica Acta Suppl. 1978;p. 85-99.

42. Darvish S, Etemad K, Mosaheb A, Yazdanpanah G. Comparing Maternal and Neonatal Side Effects of Natural Vaginal Deliv- ery under Neuro-Axial Analgesia with Usual Vaginal Delivery and Cesarean Section: A Primary Single Center Study. J Obstet Gynecol Cancer Res In Press (In Press): e11411 Published online. 2017;

43. Firouzi $M$, Yazdanmehr R, Elyasi $H$, Birjandi M, Goudarzi A, Almasian $M$. The prevalence of the $A B O$ hemolytic disease of the newborn and its complications in an Iranian population. Iranian Journal of Pediatric Hematology and Oncology. 2018;7:37-47.

44. Chang YH, Yang SH, Wang TF, Lin TY, Yang KL, Chen SH. Complete blood count reference values of cord blood in Taiwan and the influence of gender and delivery route on them. Pediatrics and Neonatology. 2011;52:155-60. Available from: DOI:10.1016/j.pedneo.2011.03.007.

45. Qaiser DH, Sandila MP, Kazmi T, Ahmed ST. Influence of maternal factors on hematological parameters of healthy newborns of Karachi. Pakistan Journal of Physiology. 2009;5:34-37.

46. Nikischin W, Peter M, Oldigs HD. The influence of mode of delivery on hematologic values in the umbilical vein. Gynecologic and Obstetric Investigation. 1997;43:104-7. Available from: Doi:10.1159/000291831.

47. Boma H, Borna S, Rafati SH. Haji Ebrahimi Tehrani.Umbilical cord hematologic in different mode of delivery. Tehran University Medical Journal. 2006;64:49-56.

48. Esfarjani SV. Asgharinejad L. Correlation beetwean mean hemoglobin of umblicul cord who were borned in razi hospital. Majallah-i Danishkadah-i Pizishki-i Isfahan. 2006;82:21-5.

49. Zibad HA, Moghadam KB, Moghadam MB, Binabaj NB, Rafat E. The Correlation between Type of Delivery and Umbilical Cord Blood Hemoglobin and Hematocrit in Full-Term Neonates. Majallah-i Danishkadah-i Pizishki-i Isfahan. 2012;29.

50. Hematyar M, Ekhtiari A. Correlation between neonatal cord blood hemoglobin and hematocrit with mode of delivery. JQUMS. 2008;12:22-3.

51. Marwaha N, Marwaha RK, Narang A, Thusu K, Garewal G, Bhakoo ON. Routine hematological values in term newborns. Indian Pediatrics. 1992;29:1095-9.

52. Sheffer-Mimouni G, Mimouni FB, Lubetzky R, Kupferminc $M$ Deutsch V, Dollberg S. Labor does not affect the neonatal absolute nucleated red blood cell count. American Journal of Perinatology. 2003;20:367-71. Available from: DOI:10.1055/ s-2003-45285.

53. Zhou YB, Li HT, Zhu LP, Liu JM. Impact of cesarean section on placental transfusion and iron-related hematological indices in term neonates: a systematic review and meta-analysis. Placenta. 2014;35:1-8. Available from: DOI:10.1016/j.placenta. 2013.10.011.

54. Chang YH, Yang SH, Wang TF, Lin TY, Yang KL, Chen SH. Complete blood count reference values of cord blood in Taiwan and the influence of gender and delivery route on them. Pediatrics and Neonatology. 2011;52:155-60. Available from DOI:10.1016/j.pedneo.2011.03.007.

55. Wu JH, Chou HC, Chen PC, Jeng SF, Chen CY, Tsao PN. Impact of delivery mode and gestational age on haematological parameters in Taiwanese preterm infants. Journal of Paediatrics and Child Health. 2009;45:332-6. Available from: DOI: 10.1111/j.1440-1754.2009.01497.x.

56. Fady M, Alif A, Maha M, Rania K. Haematological parameters of newborns delivered vaginally versus caesarean section. Menoufia Medical Journal. 2016;29:259-64. Available from: Doi:10.4103/1110-2098.192429.

57. Lee HR, Shin S, Yoon JH, Kim BJ, Hwang KR, Kim JJ. [Complete blood count reference values of donated cord blood from Korean neonates]. The Korean Journal of Laboratory Medicine. 2009;29:179-84. Available from: DOI:10.3343/kjlm.2009.29.3. 179.

58. Acharya G, Sitras V. Oxygen uptake of the human fetus at term. Acta Obstetricia et Gynecologica Scandinavica. 2009;88:1049. Available from: Doi:10.1080/00016340802460339.

59. Eskola M, Juutistenaho $S$, Aranko $K$, Sainio $S$, Kekomäki R. Association of cord blood platelet count and volume with 
hemoglobin in healthy term infants. Journal of Perinatology.

2011;31:258-62. Available from: DOI:10.1038/jp.2010.95.

60. Noguera NI, Detarsio G, Perez SM, Bragos IM, Lanza O, Ro- driguez $\mathrm{JH}$, et al. Hematologic study of newborn umbilical cord blood. MEDICINA-BUENOS AIRES-. 1999;59:446-448. 